\title{
ANALISIS KEBIJAKAN AKUNTANSI PSAK 16 TENTANG ASET TETAP PADA CV. DIAN AYU SETIABUDI BREBES
}

\section{Hilda Kumala Wulandari}

Fakultas Ekonomi dan Bisnis Universitas Muhadi Setiabudi Brebes

Email: hildakumala_wulandari@yahoo.com

\section{Abstract}

CV. Dian Ayu Setiabudi is a distributor company that is engaged in the sale of Unilever products in Brebes, which has large enough fixed assets so that it needs good asset management following the statement of financial accounting standards (PSAK) 16 so that it has an impact on the progress of the company's asset management. In managing company assets, accounting is one of the economic and financial systems used to manage assets owned by the company. The research method used in this research is descriptive qualitative research. The data collection techniques in the form of interviews, observation, documentation, and triangulation of data in the CV. Dian Ayu Setiabudi. Based on the results of the research conducted, it can be concluded that 1. Accounting Policies PSAK 16 regarding fixed assets is one of the normative bases in implementing asset accounting records that can be used by all institutions and companies so that there are no mistakes and errors in their management. 2. Management of the implementation of fixed asset accounting CV. Dian Ayu Setiabudi, Brebes Regency, has basically implemented accounting policies following the Statement of Financial Accounting Standards (PSAK) No. 16 regarding fixed assets, although not maximized, the accounting policies carried out include asset recognition, asset measurement, asset expenditure, fixed asset depreciation, termination and disposal of fixed assets even presentation and disclosure of fixed assets.

Keywords: Policy; PSAK 16; Fixed Assets

\section{Abstrak}

CV. Dian Ayu Setiabudi merupakan salah satu perusahaan distributor yang bergerak dalam penjualan produk-produk unilever di Brebes memiliki asset tetap yang cukup besar sehingga perlu pengelolaan asset yang baik sesuai dengan pernyataan standar akuntansi keuangan (PSAK) 16 sehingga berdampak pada kemajuan pengelolaan asset perusahaan. Dalam pengelolaan asset perusahaan, akuntansi menjadi salah satu system ekonomi dan keuangan yang digunakan untuk mengelola asset yang dimiliki perusahaan. Metode penelitian yang digunakan dalam penelitian ini adalah penelitian kualitatif deskriptif. Adapun teknik pengumpulan datanya berupa wawancara, observasi, dokumentasi dan triangulasi data yang ada di CV. Dian Ayu Setiabudi. Berdasarkan hasil penelitian yang dilakukan dapat disimpulkan bahwa 1. Kebijakan Akuntansi PSAK 16 tentang asset tetap menjadi salah satu landasan normative dalam mengimplementasikan pencatatatan akuntansi asset yang dapat dipergunakan oleh seluruh institusi maupun 
perusahaan sehingga tidak ada kekeliruan dan kesalahan dalam pengelolaannya. 2 . Pengelolaan pelaksanaan akuntansi aset tetap CV. Dian Ayu Setiabudi Kabupaten Brebes pada dasarnya telah menerapkan kebijakan akuntansi sesuai dengan Pernyataan Standar Akuntansi Keuangan (PSAK) No.16 tentang asset tetap walaupun belum maksimal, kebijakan akuntansi yang dilakukan meliputi pengakuan asset, pengukuran asset, pengeluaran asset, penyusutan asset tetap, penghentian dan pelepasan asset tetap bahkan penyajian dan pengungkapan asset tetap.

Kata kunci: Kebijakan; PSAK 16; Aset Tetap

\section{Pendahuluan}

Akuntansi menurut American institute of Certified Public Accounting (AICPA) menyatakan adalah "ilmu dan seni pencatatan, pengorganisasian dan pengikhtisaran dalam kajian moneter, transakasi dan segala sesuatu yang berkaitan dengan keuangan dan penafsiran hasil-hasilnya" (Harahap, 2011). Menurut (Suwardjono, 2013), kata akuntansi berasal dari kata bahasa Inggris to account yang berarti memperhitungkan atau mempertangungjawabkan. Kata akuntansi sebenarnya diserap dari kata accountancy yang berarti hal-hal yang bersangkutan dengan accountant (akuntan) atau hal-hal yang dikerjakan oleh akuntan dalam menjalankan profesinya.

Akuntansi adalah seni, ilmu dan proses untuk mengidentifikasi, mengukur, mengklasifikasi, membukukan dan melaporkan informasi yang memungkinkan pembuatan keputusan bagi pihak yang berkepentingan dalam periode tertentu. Aktiva tetap merupakan salah satu bagian utama yang dimiliki perusahaan sebagai kekayaan yang berjumlah besar dan mengalami penyusutan dalam satu periode akuntansi (Budiman, Pangemanan, \& Tangkuman, 2014). Adanya akuntansi pada perusahaan memiliki tujuan yaitu untuk memberikan informasi dan pengelolaan data ekonomi dari pihak-pihak yang memiliki kepentingan baik internal maupun eksternal. Salah satu kegiatan akuntansi adalah pengelolaan kegiatan-kegiatan operasional produksi yang dijalankan perusahaan. Kegiatan produksi yang dihasilkan perusahaan dapat berupa barang ataupun jasa sehingga outputnya dapat menghasilkan laba yang maksimal. Hal ini dapat dilaksanakan jika dalam pelaksanaan manajemennya mempertimbangkan aspek-aspek yang mempengaruhinya yakni memberikan pelayanan yang baik dan terstruktur yang mengacu pada lima fungsi manajemen organisasi yaitu perencanaan (planning), pengelompokan (organising), pelaksanaan (activating) evaluasi (evaluating) dan pengawasan (controlling) sebagai bentuk dari upaya memajukan pengembangan usaha (Ridwan, 2019).

Penghasilan keuntungan yang optimal sangat menguntungkan bagi perusahaan untuk pencapaian tujuan dan kelangsungan hidup perusahaan. Salah satu faktor produksi yang harus dimiliki perusahaan adalah faktor produksi modal, yaitu berupa aktiva tetap khususnya aktiva tetap berwujud. Meskipun dana yang dibutuhkan untuk aktiva tetap sangat besar dan investasinya bersifat permanen, namun aktiva tetap sangat sangat penting dalam penunjang aktivitas perusahaan. Aktiva tetap merupakan harta 
berwujud yang diperoleh dalam bentuk siap pakai atau dibangun terlebih dahulu, yang digunakan dalam operasi perusahaan dan mempunyai masa manfaat lebih dari satu tahun Perolehan aktiva tetap dapat dilakukan dengan berbagai cara sesuai dengan kebijakan manajemen yang dianggap akan menguntungkan bagi perusahaan, setiap cara perolehan akan memengaruhi harga perolehannya. (Tantia, 2018).

Menurut (Niswonger \& Reeve, 2000) Akuntansi merupakan suatu sistem informasi yang memberikan laporan kepada pihak-pihak berkepentingan mengenai kegiatan ekonomi dan kondisi perusahaan. Di Indonesia penyajian laporan keuangan yang berlaku umum yang sesuai dengan prinsip akuntansi biasanya mencakup pengungkapan informasi yang valid atas hal-hal material dan informasi penyajian laporan keuangan yang sesuai fakta sehibngga memberikan suatu keputusan yang dapat berpengaruh terhadap pengukuran nilai wajar pada suatu harta atau aset perusahaan karena dapat dikatakan hampir seluruh perusahaan yang bergerak di bidang jasa maupun industri biasanya menginvestasikan modalnya dalam bentuk harta yang bersifat tahan lama yang disebut aset tetap. Akuntansi merupakan salah satu sarana untuk mengelola aset tetap agar sesuai dengan kebutuhan manajemen.

Pada hakikatnya perusahaan dimanapun menghendaki tujuan yang sama yakni ingin mendapatkan keuntungan. Tujuan utama didirikannya sebuah perusahaan adalah untuk memperoleh laba yang optimal atas investasi yang telah ditanamkan sehingga dapat mempertahankan kelancaran usaha dalam jangka waktu yang panjang (Effendi, 2015). Untuk mendapatkan keuntungan yang diingikan tersebut perusahaan biasanya memiliki beberapa hal yang dapat dilakukan untuk menunjang keberlangsungan dan aktifitas perusahan. Salah satu penunjang yang dimiliki sebuah perusahaan yaitu aset. Aset dalam sebuah perusahaan dibagi menjadi berbagai macam misalnya aset tetap berwujud, aset tetap tidak berwujud dan aset lancar. Perusahaan sangat berpengaruh jika aset yang dimiliki tidak memadai karena tanpa adanya aset suatu perusahaan sulit untuk berdiri seperti contoh aset tetap berwujud yakni bangunan, tanah, peralatan, kendaraan, dan sebagainya. Aset lancar seperti kas, piutang, dan sebagainya. sedangkan aset tetap tidak berwujud misalnya hak paten, HAKI, dan sebagainya. Dalam aspek standar akuntansi dan keuangan, Indonesia harus menggunakan standar akuntansi dan keuangan yang berlaku dan diterima di seluruh dunia (Jannah \& Diantimala, 2018).

Sesuai dengan aturan yang berlaku pada Pernyataan Standar Akuntansi Keuangan disebutkan bahwa aset pada seluruh perusahaan harus dicatat hal ini dilakukan untuk menghindari kekeliruan dalam pencatatan akuntansi barang sehingga dengan ketentuan aset tetap berwujud uang diatur dalam PSAK 16 (revisi 2011). Menurut PSAK 16 aset tetap adalah aset berwujud yang dimiliki perusahaan yang digunakan untuk proses produksi, penyediaan barang atau jasa dan dapat direntalkan kepada pihak lain, atau untuk tujuan administratif, dan diharapkan untuk digunakan selama lebih dari satu periode. Proses pencatatan akuntansi sangat penting karena berkaitan dengan kepemilikan khususnya pencatatan aset tetap berwujud. Pencatatan aset tetap menurut PSAK No.16 dimulai dari ketika memperoleh aset sampai adanya penghapusan aset. 
Aset dapat dimiliki dengan berbagai macam caranya yaitu dengan cara dibeli, dibuat, tukar menukar maupun pemberian/hibah. Setiap proses mulai memperoleh aset perlu dicatat dan diakui oleh perusahaan sebagai bentuk kepemilikan. Aset juga memiliki penurunan nilai dikarenakan masa usianya, penentuan usia aset dapat dihitung secara akuntansi yang diatur dalam PSAK 16. Saat aset akan dihilangkan/dihapus/dibuang maka akan ada pencatatan sendiri dan perhitungannya (Susyanti, Pranaditya, \& Hartono, 2017).

Aset dapat memberikan manfaat dimasa yang akan datang karena aset merupakan sumber ekonomi yang diharapkan perusahaan atau entitas terkait. Dalam neraca klasifikasi aset yang telah diakui disajikan dengan klasifikasi sesuai dengan standar akuntansi keuangan yang berlaku. Dalam standar akuntansi pada umumnya aset dikelompokkan menjadi aset lancar dan aset tidak lancar. Aset lancar terdiri dari beberapa pos sedangkan aset tidak lancar masih dapat dikelompokkan lagi dalam beberapa klasifikasi, antara lain : investasi atau penyertaan, aset tetap, aset tidak berwujud dan aset-aset lainnya. Pada kenyataannya aset sebuah perusahaan cenderung menjadi salah satu hal yang dipentingkan karena memiliki nilai jual yang cukup tinggi pada sebuah perusahaan. Aset sendiri juga dapat diklasifikasikan sebagai bentuk modal dan kepemilikan dari perusahaan yang diperolehnya.

Aset tetap perusahaan dapat dikatakan sesuai dengan kualifikasi dan kategori layak jika aset tersebut didapat dari biaya perolehan modal sebuah perusahaan dengan komponen biaya perolehan sesuai menurut PSAK No.16 ((IAI), 2012) tentang aset tetap meliputi:

1. Harga perolehannya, termasuk didalamnya adalah biaya impor dan pajak pembelian yang tidak dapat dikreditkan setelah adanya diskon pembelian dan potongan lain;

2. Aset dapat dibawa ke lokasi dengan kondisi yang diinginkan setelah biaya tersebut dapat didistribusikan agar aset tersebut dapat digunakan sesuai dengan keinginan manajemen;

3. Perkiraan pertama pada biaya pembongkaran dan pemindahan aset tetap dan restorasi lokasi aset tetap. Kewajiban tersebut timbul ketika aset tetap diperoleh atau sebagai skibat dari pemanfaatan aset tetap selama periode tertentu untuk tujuan selain memproduksi persediaan selama periode tersebut. (Djafar, 2018).

Perusahan merupakan organisasi modern yang mempunyai kegiatan tertentu dalam mencapai suatu tujuan, baik itu perusahaan jasa, perusahaan dagang maupun perusahaan manufaktur. Biasanya disamping mencari laba, tujuan perusahaan yaitu mencakup pertumbuhan yang terus menerus, kelangsungan hidup, dan kesan positif di mata publik. Dalam mendukung perkembangan perusahaan dibutuhkan adanya informasi keuangan (Martani, Veronica, Wardani, Farahmita, \& Tanujaya, 2012). Untuk menjalankan suatu bidang usaha, perusahaan memiliki aset yang diharapkan dapat memberikan manfaat ekonomi bagi perusahaan di masa yang akan datang. Dari beberapa jenis aktiva, ada salah satu aset yang penting dalam menunjang operasional perusahaan, yaitu aset tetap. (Martani et al., 2012). Dalam kelancaran operasional perusahaan aset tetap memiliki peran yang sangat penting untuk perusahaan dan untuk 
itu diperlukan kebijakan yang tepat dalam pengelolaan aset tetap. Di dalam PSAK No.16 akuntansi aset tetap terbagi atas enam poin yaitu Pengakuan Aset, Pengeluaran Aset Tetap, Pengukuran Aset Tetap, Penyusutan Aset Tetap, Penghentian dan Pelepasan Aset Tetap, dan Penyajian dan Pengungkapan Aset Tetap".

CV. Dian Ayu Setiabudi merupakan salah satu perusahaan distributor produk unilever yang lokasinya di Kabupaten Brebes dengan operasionalnya dalam bidang perdagangan yang menggunakan aset tetap. Bagi CV. Dian Ayu Setiabudi aset tetap ini sangat dibutuhkan dalam menjalankan kegiatan operasioanalnya karena untuk menunjang proses distribusi produk yang dilaksanakan. Kehadiran CV. Dian Ayu Setiabudi pada prinsipnya untuk memenuhi kebutuhan masyarakat akan kebutuhan sehari-hari masyarakat oleh karena itu, kehadiran perusahaan ini sangat ditunggu masyarakat hal ini sesuai dengan keinginan masyarakat yang ingin melakukan segala kegiatan untuk memenuhi salah satu keinginan dan kebutuhan masyarakat yaitu tercukupinya seluruh kebutuhan primer dan sekunder bahkan tersier (Ridwan, 2020).

CV. Dian ayu Setiabudi sebagai salah satu perusahaan distributor unilever terbesar di kabupaten Brebes memiliki aset tetap yg cukup besar sehingga perlu pengelolaan aset yang baik sesuai dengan pernyataan standar akuntansi keuangan (PSAK) 16 sehingga berdampak pada kemajuan pengelolaan asset perusahaan. Berdasarkan uraian diatas, maka perlu dikaji lebih dalam untuk memahami lebih mendalam mengenai Analisis Kebijakan Akuntansi PSAK 16 Tentang Aset Tetap Pada CV. Dian Ayu Setiabudi Brebes.

\section{Metode Penelitian}

Metode penelitian yang digunakan adalah metode kualitatif, karena dalam penelitian ini untuk mencari, mendapatkan, mengumpulkan sejumlah data untuk mendapatkan gambaran fakta-fakta yang jelas dari perusahaan yang tidak dapat dihitung dengan skala numerik. Penelitian kualitatif dapat menunjukan kehidupan masyarakat, sejarah, tingkah laku, fungsionalisasi organisasi, pergerakan sosial, dan hubungan kekerabatan. (Almanshur, 2012). Data yang digunakan dalam penelitian ini bersumber dari data primer dan data sekunder. Data primer bersumber dari data perusahaan dan data sekunder penunjang dari literatur dan penelitian yang relevan yang bersumber dari riset peneliti sebelumnya. Berdasarkan uraian di atas dapat dijelaskan bahwa data primer yang digunakan dalam penelitian ini diperoleh dari data CV. Dian Ayu Setiabudi Brebes baik secara observasi, wawancara, dokumentasi maupun triangulasi data dalam penelitian yang sesuai kebutuhan. Sedangkan data sekunder dalam penelitian ini adalah data yang diperoleh dari dokumentasi arsip perusahaan, laporan keuangan tahunan perusahaan, maupun studi keperpustakaan berupa buku, jurnal, artikel, makalah, ataupun literatur lain yang relevan.

Adapun teknik pengumpulan data yang telah dilaksanakan dalam penelitian ini adalah dengan menggunakan observasi, wawancara dan dokumentasi. Setelah data terkumpul kemudian dianalisis dengan menggunakan metode analisis deskriptif, yaitu suatu metode penelitian dengan cara mencari, mengumpulkan, mencatat, menyusun, 
mengklasifikasikan, menginterpretasikan, menganalisis data, dan memberikan gambaran jawaban yang valid dan akurat.

Untuk lokasi penelitian dalam kajian ini bertempat di CV. Dian Ayu Setia Budi Brebes dengan alamat di Jalan Raya Pantura Grinting Kluwut Kec. Bulakamba kab. Brebes Jawa Tengah dengan waktu penelitian dilakukan pada tanggal 24 Februari sampai dengan tanggal 23 Maret 2020.

\section{Hasil dan Pembahasan}

\section{Kebijakan Akuntansi PSAK 16 Tentang Aset Tetap}

Kebijakan akuntansi merupakan prinsip bagi kegiatan akuntansi keuangan perusahaan yang meliputi seluruh instrumen utama dari laporan mengenai posisi aset, utang, serta modal perusahaan dan laporan perubahan dalam posisi aset, utang dan modal yang diakibatkan oleh aktivitas perusahaan untuk memperoleh laba secara periodic (Putra, 2013).

Pernyataan standar akuntansi keuangan (PSAK) 16 merupakan salah satu regulasi yang mengatur tentang pencatatatan akuntansi asset yang dimiliki perusahaan sebagai bagian dari modal kepemilikan dan investasi perusahaan tersebut. Asset memiliki peran penting dalam sebuah perusahaan karena dianggap sebagai modal dasar dalam menjalankan produksi baik jasa maupun barang untuk keberlanjutan dan keberlangsungan sebuah perusahaan. Kebijakan tentang adanya pencatatan pada akuntansi pada prinsipnya telah diatur dalam regulasi Pernyataan Standar Akuntansi Keuangan 16 (revisi 2011) dimana berisi tentang aset tetap yang terdiri dari konteks tujuan pengaturan dan kerangka dasar penyusunan dan penyajian laporan keuangan. Pernyataan ini memiliki tujuan untuk mengatur pemberlakuan akuntansi aset tetap, supaya pengguna laporan keuangan dapat memahami informasi mengenai pencatatatan akuntansi investasi entitas pada aset tetap suatu perusahaan. kajian utama dalam dokumen akuntansi aset tetap adalah pengakuan aset, penentuan jumlah tercatat, pembebanan penyusutan, dan rugi penurunan nilai atas aset tetap.

Menurut PSAK 16 tentang asset tetap, dijelaskan bahwa aset tetap adalah aset berwujud yang : (a) dimiliki untuk digunakan dalam produksi atau penyediaan barang atau jasa untuk direntalkan kepada pihak lain, atau untuk tujuan administratif; dan (b) diharapkan untuk digunakan selama lebih dari satu periode. Biaya perolehan adalah jumlah kas atau setara kas yang dibayarkan atau nilai wajar dari imbalan lain yang diserahkan untuk memperoleh suatu aset pada saat perolehan atau konstruksi, jika dapat diterapkan, jumlah yang diatribusikan ke aset pada saat pertama kali diakui sesuai dengan persyaratan tertentu dalam PSAK lain, misalnya PSAK 53 (revisi 2010): Pembayaran Berbasis Saham.

Perolehan aset tetap yang dimiliki oleh perusahaan tetap harus mempertimbangkan biaya yang dikeluarkan sebagai bagian dari kepemilikian aset perusahaan yang diakui sebagai bagian dari aset perusahaan. Suku cadang atau peralatan perusahaan yang diperoleh juga diakuisisi dan dicatat sebagai bentuk dari kepemilikan perusahaan yang dihitung dalam bentuk laba rugi perusahaan saat 
dikonsumsi. Tetapi apabila suku cadang atau aset pemeliharaan yang tersedia tidak digunakan untuk dikonsumsi perusahaan yang artinya tidak persediaannya masih ada maka tetap harus dicatat dalam akuntansi aset tetap karena hal tersebut bagian dari kepemilikan perusahaan yang dihitung dalam permodalan.

Pengakuan suatu aset tetap yang dimiliki perusahaan menjadi bagian yang harus dipertimbangkan dalam penerapan kriteria sesuai dengan kondisi perusahaan dan pihak entitas dalam mengakui sumber kepemilikan barang dan aset perusahaan. Entitas perusahaan sebagai bagian dari struktural mengevaluasi pengakuan aset berdasarkan sumber perolehan aset yang dimiliki perusahaan saat terjadi jual beli atau pembelian barang. Biaya-biaya yang dikeluarkan untuk mendapatkan aset tetap perusahaan harus tercatat dalam pembukuan akuntansi sebagai akibat dari modal yang dikeluarkan, penambahan modal, penggantian aset/barang atau perbaikan aset yang perlu renovasi atau perbaikan. Salah satu contoh dari biaya yang dikeluarkan sebagai bentuk biaya perolehan aset diantaranya (a) biaya pembangunan fasilitas yang baru; (b) biaya promosi produk yang baru; (c) biaya pembukaan bisnis baru atau kelompok pelanggan baru (termasuk biaya operasional dan training); dan (d) administrasi dan biaya lainnya yang tidak terduga.

Pengakuan aset yang dimiliki yang telah berada dilokasi perusahaan tentu dalam kepemilikannya memerlukan biaya yang dikeluarkan sehingga hal tersebut harus dicatat dalam akuntasi aset tetap sebagai bagian dari modal yang telah dikeluarkan perusahaan sesuai dengan intensitas manajemen oleh karena itu, pengembangan aset yang memerlukan biaya dalam jumlah besar tetap harus tercantum dalam pembukuan aset tetap. Namun ada juga kepemilikan aset tetap perusahaan yang tidak perlu dicatat dalam pembukuan akuntansi aset tetap sebagai contoh biaya-biaya berikut ini tidak termasuk di dalam jumlah tercatat suatu aset tetap: (a) biaya aset yang dimiliki dengan intensi manajemen namun digunakan dalam operasionalnya; (b) kerugian pada saat memulai operasional seperti penggunaan aset di awal pembukaan alat, dan (c) biaya reorganisasi atau relokasi sebagian atau seluruh operasi.

Model biaya perusahaan dapat diakui dan dicatat sebagai besaran biaya modal pengadaan aset, namun biaya tersebut perlu dikurangi dengan biaya akumulasi penyusutan dan biaya akumulasi rugi dari adanya penurunan nilai jual aset yang dimiliki saat pembelian karena biaya aset tetap yang bergerak biasanya terjadi penyusutan harga setelah beberapa tahun berlalu walapun aset tersebut tidak digunakan. Oleh karena itu, aset tetap bergerak yang dimili perlu direvaluasi untuk menentukan nilai wajar dari aset yang dimiliki dikarenakan adanya penyusutan harga, nilai wajar aset dan akumulasi rugi karena penurunan nilai aset sejak kepemilikan aset itu dimiliki. Revaluasi yang dilakukan secara teratur oleh perusahaan akan berdampak baik pada jumlah aset yang dilaporkan pada akhir periode sebagai bentuk dari laporan perusahaan dalam menjumlah aset tetap yang dimiliki setelah adanya penyusutan dan revaluasi aset. 
Setelah adanya revaluasi aset maka penyusutan aset juga akan terjadi sebagai akibat dari ekspektasi manfaat ekonomi masa depan dari aset yang dimiliki entitas. Metode penyusutan yang digunakan berfungsi untuk mengetahui jumlah aset tetap yang masih digunakan perusahaan serta mengetahui hasill revies minimum terhadap aset tetap tersebut setiap alhir tahun masa pelaporan yang tercatat dalam buku kas dan akuntansi pelaporan aset tetap. Pemberlakuan metode penyusutan tersebut dijadikan sebagai perubahan estimasi akuntansi yang sesuai dengan PSAK 25 (revisi 2009) tentang Kebijakan Akuntansi, Perubahan Estimasi Akuntansi dan Kesalahan.

Berdasarakan kebijakan akuntansi PSAK 16 tentang asset tetap dapat disimpulkan bahwa yang dimaksud asset tetap perusahaan adalah aset berwujud yang dimiliki perusahaan untuk digunakan dalam kegiatan produksi atau penyediaan barang atau jasa untuk direntalkan kepada pihak lain, atau untuk tujuan administratif dalam memberikan pelayanan serta diharapkan untuk digunakan selama lebih dari satu periode dalam pencatatan akuntansi asset yang dimiliki. Kebijakan Akuntansi PSAK 16 ini, menjadi salah satu landasan normative dalam mengimplementasikan pencatatatan akuntansi asset yang dapat dipergunakan oleh seluruh institusi maupun perusahaan sehingga tidak ada kekeliruan dan kesalahan dalam pengelolaannya.

\section{Analisis Kebijakan PSAK 16 Tentang Aset tetap pada CV. Dian Ayu Setiabudi Brebes}

1. Pengakuan.

Berdasarkan data dari CV. Dian Ayu Setiabudi bahwa pengakuan aset tetap yang dimiliki berdasarkan regulasi pernyataan standar akuntansi keuangan (PSAK) No.16 telah memberikan dampak pada manfaat ekonomi, aset tetap tersebut diperkirakan akan memberikan kegunaan, manfaat dan menunjang operasional perusahaan untuk mengoperasionalkan kegiatannya dalam memberikan pelayanan pada mahasiswa. Dalam hal ini pengakuan aset perusahaan yang dilaksanakan di CV. Dian Ayu Setiabudi telah sesuai dengan pedoman yang dimiliki oleh perusahaan dan tidak menyalahi aturan dari PSAK No. 16 tentang Aset tetap.

2. Pengeluaran Setelah Memperoleh Aset Tetap.

Dari data yang di dapat, CV. Dian Ayu Setiabudi melakukan pengeluaran dari asset yang ada untuk pemeliharaan dan perbaikan aset tetap yang dimiliki dengan mempertimbangkan waktu manfaatnya pada waktu yang akan datang dengan meningkatkan kapasitas pelayanan dan standar kerja ataupun mutu pelayanan. Pengeluaran ini dilakukan pada prinsipnya harus disesuaikan dengan jumlah tercatat pada aset yang bersangkutan. Namun pengeluaran yang dapat diakuisisi sebagai perhitungan hanya pengeluaran modal yang dimaksudkan untuk menambah nilai dari aset tetap. Sedangkan untuk pengeluaran yang tidak menambah asas manfaat diakui dalam rugi laba saat terjadinya sebagai beban. Prinsip alokasi biaya untuk pengeluaran ini tidak dikaji secara spesifik di dalam Standar Akuntansi Keuangan, namun untuk menghindari kekeliruan pada saat 
perhitungan laba untuk serangkaian periode akuntansi, maka ada baiknya pengeluaran-pengeluaran untuk aset tetap ditentukan dan dikelompokkan. Dalam kebijakan akuntansi perusahaan, dinyatakan bahwa pengeluaran untuk menambah masa manfaat dan umur ekonomis aset tetap digolongkan kedalam pengeluaran modal, dan dikapitalisasikan dengan mendebet perkiraan yang bersangkutan.

3. Pengukuran Aset Tetap.

Penilaian terhadap aset tetap perusahaan harus dilakukan berdasarkan nilai pasar atau nilai wajar aset tetap yang berlaku pada saat perusahaan menetapkan nilai wajar atau penilaian asset dilakukan oleh ahli penilai yang diakui/memperoleh izin pemerintah (Waluyo, 2012). Berdasarkan penelitian mengenai perlakuan akuntansi aset tetap pada CV. Dian Ayu Setiabudi, bahwa pengukuran asset tetap perlu dilakukan sebagai bentuk dari evaluasi dan penilaian asset yang dimiliki oleh perusahaan CV. Dian Ayu Setiabudi. Pada prinsipnya kebijakan perusahaan menyatakan bahwa anggaran perolehan aset tetap yang dimiliki terdiri dari harga beli aset tetap dan anggaran yang dikeluarkan hingga aset tersebut siap digunakan. Aset tetap yang diperoleh melalui jual beli pada transaksi keuangan, berdasarkan nilai wajar dari asest yang diperoleh pencatatannya dibukukan dalam akuntansi asset yang dimiliki perusahaan. Pencatatan transaksi asset yang dimiliki tidak dijelaskan dengan rinci, sedangkan perlakuan aset tetap yang diakui dalam kebijakan perusahaan telah sesuai dengan regulasi standar akuntansi yang berlaku. Untuk aset yang dibangun sendiri, dicatat berdasarkan total anggaran yang dikeluarkan hingga aset tetap tersebut siap digunakan. Aset tetap yang dibangun oleh perusahaan, tentu memerlukan adanya kerja sama dengan pihak ketiga yaitu kontraktor untuk membuat rancangan gedung yang akan dibangun, memperkirakan biaya yang dikeluarkan sampai bangunan asset tersebut siap digunakan karena bangunan yang telah siap digunakan setelah dibangun dalam akuntansi asset dapat menjadi hak dan kepemilikan dari perusahaan tersebut.

Berdasarkan tinjauan regulasi PSAK No. 16 hal ini tidak menyimpang, namun secara praktik yang telah dilakukan ternyata perusahaan tidak menjelaskan secara detail program perencanaan dan taksiran biaya yang dikeluarkan untuk membangun gedung, pencatatatan biaya yang dikeluarkan pihak ketiga juga tidak secara rinci dibukukan berdasarkan akuntansi sehingga hal tersebut menjadi salah satu problematika dalam pencatatan akuntansi asset tetap walaupun telash sesuai dengan prosedur regulasi PSAK 16 yang telah ditetapkan.

Sebagai bagian dari evaluasi dan kontrol manajemen, perusahaan dapat menerapkan kebijakan revaluasi yakni penilaian evaluasi kembali terhadap aset tetap yang dimiliki apabila sudah diperoleh dasar yang otoritatif. Menurut aturan Standar Akuntansi Keuangan, jika perusahaan menggunakan model revaluasi dalam penilaian asetnya, maka pada saat aset diakui, aset tetap yang dicatat pada 
jumlah revaluasinya. Jika dilihat dari pedoman kebijakan yang dimiliki, Perusahaan CV. Dian Ayu Setiabudi sudah menerapkan Standar Akuntansi Keuangan sesuai PSAK No.16 namun mremiliki kelemahan dalam pencatatan asetnya yakni dalam pencatatan aset, perusahaan tidak menjelaskan secara detail bahwa perusahaan pernah melakukan revaluasi dan pencatatan aset pada nilai revaluasiannya.

4. Penyusutan Aset Tetap.

Asset yang dimiliki CV. Dian Ayu Setiabudi berdasarkan kebijakan PSAK No. 16 telah mengalami penyusutan, dimana aset tetap perusahaan yang dimiliki yang telah disusut secara terpisah. CV. Dian Ayu Setiabudi melakukan proses penyusutan aset tetap dengan metode saldo menurun dan metode garis lurus. Aset tetap yang dimiliki berupa bangunan, kendaraan, peralatan kantor dan inventarisnya mengalami perlakuan penyusutan yang sama. Biaya yang dikeluarkan dari proses penyusutan aset tetap dimasukkan dalam daftar pencatatan akuntansi aset tetap yang diakui secara publik bahwa aset yang dimiliki merupakan bagian dari modal perusahaan. Berdasarkan hasil penelitian yang dilaksanakan bahwa kebijakan perusahaan CV. Dian Ayu Setiabudi telah menerapkan pemberlakuan penyusutan aset sesuai dengan PSAK No.16.

5. Penghentian dan Pelepasan Aset Tetap.

Menurut (Giri, 2012) ada beberapa transaksi yang dapat menghentikan pemakaian aset tetap yaitu berakhirnya masa manfaat aset tetap, transaksi penjualan aset tetap, dan pertukaran dengan aset lain. Berdasarkan data hasil penelitian tentang aset bahwa aset tetap yang dimiliki CV. Dian Ayu Setiabudi yang sudah tidak digunakan lagi atau tidak terpakai maka akan dihapus dari dalam buku pencatatan akuntansi yang diakui sebagai aset tetap perusahaan. Hal ini dimaksudkan agar dapat memisahkan mana aset yang masih digunakan dengan yang sudah tidak digunakan namun aset yang sudah dihapus tetap dicatat sebagai aset yang sudah tidak digunakan lagi oleh perusahaan dan boleh dibuang sebagai bentuk laporan epenghentian atas aset yang dimiliki, kebijakan tersebut telah dipahami bersama bawa perusahaan tidak menyalahi aturan yang ditetapkan berdasarkan Standar Akuntansi Keuangan. CV. Dian Ayu Setiabudi mengakui bahwa pemberlakuan tersebut memiliki keuntungan atau kerugian dalam laporan laba rugi berkaitan dengan pelepasan aset tetap yang bersangkutan. Hal ini dapat dikatakan bahwa aset uyang telah dibuang walaupun kondisinya masih baik atau kurang layak digunakan dapat dijual dan keuntungan dari penjualan tersbut tetap harus diakui sebagai keuntungan yang diperoleh perusahaan dalam penjualan aset yang dilakukan sebagai contoh, ketika aset tetap dilepas dengan cara dijual maka keuntungan dari penjualan aset tetap harus diakui perusahaan. Berdasarkan PSAK No 16 tentang aset bahwa penghapusan aset atau pelepasan aset yang dimiliki perusahaan dengan cara dijual atau dilelang dan aset tersebut laku maka keuntungan dari hasil penjualan tersebut harus masuk dalam pembukuan aset hasil keuntungan penjualan aset yang 
dilakukan dan hal ini telah dilaksanakan oleh perusahaan CV. Dian Ayu Setiabudi sebagai bagian dari penerapan PSAK No.16 tentang aset tetap.

6. Penyajian dan Pengungkapan Aset Tetap.

Berdasarkan data dari hasil penelitian yang dilaksanakan di CV. Dian Ayu Setiabudi, dijelaskan bahwa perusahaan telah menyajikan aset tetap yang sesuai dengan pembukuan akuntansi yang nilainya sama yakni harga perolehan aset dikurangi akumulasi penyusutan, hal tersebut sesuai dengan aturan PSAK No. 16. Pada institusi, jenis aset tetap yang dimliki perusahaan CV. Dian Ayu Setiabudi seperti aset tanah, bangunan, gedung, dan aset lain yang telah disajikan dan diakuisisi sebagai aset yang dimiliki harus tercatat sebagai aset tetap perusahaan dan hal ini sesuai dengan aturan PSAK No.16. Pengungkapan aset tetap perusahaan CV. Dian Ayu Setiabudi dituangkan secara langsung dalam neraca keuangan yang berupa catatan atas laporan keuangan.

\section{Kesimpulan}

Berdasarkan hasil penelitian dan pembahasan tentang Analisis Kebijakan Akuntansi PSAK 16 Tentang Aset Tetap Pada CV. Dian Ayu Setiabudi Kabupaten Brebes maka dapat disimpulkan bahwa kebijakan akuntansi berdasarkan PSAK 16 tentang asset tetap menjadi salah satu landasan normative dalam mengimplementasikan pencatatatan akuntansi asset yang dapat dipergunakan oleh perusahaan sehingga tidak ada kekeliruan dan kesalahan dalam pengelolaannya. Kegiatan akuntansi dalam pengelolaan aset tetap CV. Dian Ayu Setiabudi Kabupaten Brebes pada dasarnya telah menerapkan kebijakan akuntansi sesuai dengan Pernyataan Standar Akuntansi Keuangan (PSAK) No.16 tentang asset tetap walaupun belum maksimal, kebijakan akuntansi yang dilakukan meliputi pengakuan asset, pengukuran, pengeluaran aset, penyusutan aset tetap, penghentian dan pelepasan aset tetap bahkan penyajian dan pengungkapan aset tetap. 


\section{BIBLIOGRAFI}

Ikatan Akuntan Indonesia. (2012). Standar Akuntansi Keuangan PSAK. Jakarta: Salemba Empat.

Almanshur, M. Djunaed. Ghony dan Fauzan. (2012). Metodologi Penelitian Kualitatif. Yogyakarta: Ar-Ruz Media.

Budiman, Erwin, Pangemanan, Sifrid, \& Tangkuman, Steven. (2014). Analisis Perlakuan Akuntansi Aktiva Tetap pada PT. Hasjrat Multifinance Manado 2012. Jurnal EMBA: Jurnal Riset Ekonomi, Manajemen, Bisnis Dan Akuntansi, 2(1).

Djafar, Juliana Sartika. (2018). Akuntansi Aset Tetap Kendaraan Berdasarkan PSAK 16 Tahun 2015 (Studi Kasus pada PT. XYZ).

Effendi, Rizal. (2015). Analisis perlakuan akuntansi atas aset tetap berdasarkan SAK ETAP pada CV. Sekonjing Ogan Ilir. Palembang. Statement and Fixed Assets.

Giri, Efraim Ferdinan. (2012). Akuntansi Keuangan Menengah 1. Yogyakarta: Upp Stim Ykpn.

Harahap, Sofyan Syafri. (2011). Teori Akuntansi Edisi Revisi. Jakarta: PT Raja Grafindo Persada.

Jannah, Raudhatul, \& Diantimala, Yossi. (2018). Faktor-Faktor Yang Mempengaruhi Perusahaan Melakukan Revaluasi Aset Tetap Sesuai Dengan PSAK 16 (2015) Di Indonesia. Jurnal Ilmiah Mahasiswa Ekonomi Akuntansi, 3(3), 515-526.

Martani, Dwi, Veronica, Sylvia, Wardani, Ratna, Farahmita, Aria, \& Tanujaya, Edward. (2012). Akuntansi Keuangan Menengah Berbasis PSAK. Jakarta: Salemba Empat.

Niswonger, Warren, \& Reeve, Fess. (2000). Prinsip-prinsip Akuntansi (edisi 19). Jilid I, Jakarta, Penerbit Erlangga.

Putra, Trio Mandala. (2013). Analisis penerapan akuntansi aset tetap pada CV. Kombos Manado. Jurnal EMBA: Jurnal Riset Ekonomi, Manajemen, Bisnis Dan Akuntansi, 1(3).

Ridwan, Mohammad. (2019). Pengelolaan Zakat Dalam Pemberdayaan Masyarakat di Kota Cirebon. Syntax Idea, 1(4).

Ridwan, Mohammad. (2020). Upaya Masyarakat Dalam Publikasi Destinasi Wisata Untuk Peningkatan Ekonomi Desa Leuwikujang Kec. Leuwimunding Kab. Majalengka. Ecopreneur: Jurnal Program Studi Ekonomi Syariah, 1(1), 30-45.

Susyanti, Steela Alfani, Pranaditya, Ari, \& Hartono, Hartono. (2017). Evaluasi Penerapan PSAK 16 Mengenai Aset Tetap Pada Pencatatan Tanah, Bangunan, Dan Mesin Di PT Dong Bang Indo Tengaran. Journal Of Accounting, 3(3). 
Suwardjono. (2013). Akuntansi Pengantar (Edisi Keen). Yogyakarta: BPFE.

Tantia, Myrna Dwi. (2018). Penerapan Akuntansi Aktiva Tetap Menurut Psak No. 16 Pada PT Perkebunan Nusantara III (Persero) Medan. Universitas Islam Negeri Sumatera Utara Meddan.

Waluyo. (2012). Akuntansi Pajak. Jakarta: Salemba Empat. 